\title{
Anti-tumor effects of bakuchiol on human gastric carcinoma cell lines are mediated through PI3K/AKT and MAPK signaling pathways
}

\author{
LONG LV' ${ }^{1}$ and $\mathrm{BO} \mathrm{LIU}^{2}$ \\ Departments of ${ }^{1}$ Normal Surgical, and ${ }^{2}$ Oncology, Xiangyang Central Hospital, Hubei \\ University of Arts and Science, Xiangyang, Hubei 441053, P.R. China
}

Received February 13, 2015; Accepted February 2, 2017

DOI 10.3892/mmr.2017.7696

\begin{abstract}
Bakuchiol is extracted from Psoralea corylifolia, a member of the Leguminosae family, has been used in Indian Ayurvedic and Chinese traditional medicine, and it possesses an anticancer effect. The primary aim of the present study was to identify the molecular mechanisms underlying the anticancer effect of bakuchiol monoterpenes. Bakuchiol treatment significantly inhibited NUGC3 human gastric cancer cell viability in a concentration dependent manner. In addition, bakuchiol significantly increased the apoptotic cell population in the sub-G1 phase, and Annexin-V-fluorescein isothiocyanate/propidium iodide double staining confirmed the increase in apoptosis. Nuclear fragmentation and the formation of apoptotic organelles were promoted in bakuchiol-treated NUGC3 cells. Western blotting results indicated that bakuchiol treatment significantly decreased procaspase-3,6,8,9 and poly (ADP-ribose) polymerase (PARP) expression levels, increased cleaved caspase- 3 and cleaved PARP expression levels, and increased the B cell lymphoma-2 associated $\mathrm{X}$, apoptosis regulator:B cell lymphoma-extra large ratio. Bakuchiol-treated NUGC3 cells demonstrated significantly reduced phosphorylated (p-) protein kinase B (AKT) protein expression levels and elevated p-extracellular signal related kinase 1/2 (ERK1/2), p-c-Jun $\mathrm{N}$-terminal kinase (JNK) and p-p38. Bakuchiol-induced cell death was mitochondrial dependent, through modulation of phosphoinositide 3-kinase/AKT and mitogen-activated protein kinase signaling pathways. These findings demonstrated that bakuchiol possesses potential for treating human gastric cancer.
\end{abstract}

Correspondence to: $\mathrm{Dr}$ Bo Liu, Department of Oncology, Xiangyang Central Hospital, Hubei University of Arts and Science, 136 Jingzhou Road, Xiangyang, Hubei 441053, P.R. China

E-mail: 1bliubob@hotmail.com

Key words: bakuchiol, gastric cancer, phosphoinositide 3-kinase/AKT, mitogen-activated protein kinase

\section{Introduction}

Gastric cancer is one of the most common malignant cancers globally. It is estimated that gastric cancer alone causes almost $10 \%$ of all cancer-associated mortality with a higher (10-12\%) incidence rate in Asia and Europe (1). Despite global reductions in prevalence and mortality over the past 20 years, gastric cancer is still ranked as the second major cause of cancer-associated mortality and considered as the foremost gastrointestinal infectious disease in eastern Asia (2). Understanding of the molecular mechanisms underlying gastric cancer have improved, but there remains a distinctive lack of targeted treatments in the clinical development of the disease (3). Therefore, there is a necessity to establish novel therapeutic agents that diminish the mortality rate of patients with gastric cancer, with minor side effects.

Plant-derived natural products have been used as a source of medicinal agents useful to treat humans, and the hunt for novel, effective therapeutic compounds continues. Bakuchiol is a typical prenylated monoterpene phenolic compound separated from Psoralea corylifolia, a member of the Leguminosae family. Previous reports have demonstrated that molecular structures containing styryl moieties in conjugation with other structural features, including chromones, quinazolines and pyrenes, have multiple biological uses including the treatment of cancer and HIV (4-7). Bakuchiol has previously been demonstrated to exhibit cytotoxicity in certain human cancer cell lines (8). Based on these prior examinations, the present study investigated the anticancer effects of bakuchiol in gastric cancer, aiming to produce novel insights to enhance understanding of the underlying molecular mechanism.

\section{Materials and methods}

Materials and reagents. Bakuchiol (Fig. 1), MTT reagent and dimethyl sulfoxide (DMSO) were ordered from Sigma Aldrich; Merck KGaA (Darmstadt, Germany). Cell culturing RPMI-1640 medium, fetal bovine serum (FBS) and penicillin/streptomycin antibiotics were obtained from Gibco; Thermo Fisher Scientific, Inc. (Waltham, MA, USA). Anti-rabbit monoclonal B cell lymphoma-2 associated $\mathrm{X}$, apoptosis regulator (Bax; cat. no. ab32503; 1:1,000), anti-rabbit monoclonal B cell lymphoma-extra large (Bcl-xL; cat. no. ab32370; 1:1,000), 
anti-rabbit monoclonal procaspase-3 (cat. no. ab32150; 1:500), anti-rabbit monoclonal procaspase-6 (cat. no. ab3263, 1:800), anti-mouse monoclonal procaspase-8 (cat. no. ab38271; 1:1,000) and anti-rabbit polyclonal procaspase-9 (cat. no. ab135544; 1:800), anti-rabbit monoclonal poly (ADP-ribose) polymerase (PARP; cat. no. ab191217; 1;1,000), anti-rabbit monoclonal cleaved PARP (cat. no. ab32064; 1:1,200), anti-rabbit monoclonal protein kinase B (AKT; cat. no. ab183758; 1:1,000), anti-rabbit monoclonal phosphorylated (p-AKT; cat. no. ab81283; 1;800), anti-rabbit monoclonal, p-c-Jun N-terminal kinase (JNK; cat. no. ab179461; 1:1,200), anti-rabbit monoclonal extracellular signal-regulated kinase 1/2 (ERK1/2; cat. no. ab184699; 1:1,000), anti-rabbit polyclonal cleaved caspase-3 (cat. no. ab2302; 1:1,200), anti-rabbit monoclonal $\beta$-actin (cat. no. ab32575; $1 ; 1,500)$ and anti-mouse monoclonal $\beta$-actin (cat. no. ab8226; 1:1,500) antibodies were purchased from Abcam (Cambridge, UK). Horseradish peroxidase-conjugated goat anti-mouse immunoglobulin $\mathrm{G}$ (IgG; cat. no. ab97023; 1:10,000) and anti-rabbit IgG (cat. no. ab6721; 1:10,000) were also obtained from Abcam (Cambridge, UK). The Muse Annexin V and Dead Cell Assay kit (cat. no. MCH100105) and the Muse Cell Cycle Assay kit (cat. no. MCH100106) were ordered from EMD Millipore (Billerica, MA, USA). DAPI was obtained from Vector Laboratories, Inc. (Burlingame, CA, USA). All other chemicals and materials utilized for electrophoresis were acquired from Bio-Rad Laboratories, Inc. (Hercules, CA, USA).

Cell culture. NUGC3 human gastric cancer cell lines were purchased from the Japanese Health Science Research Resources Bank (Osaka, Japan). The cells were cultured in RPMI-1640 medium and supplemented with heat-inactivated $10 \%$ FBS (v/v) and $1 \%$ penicillin and streptomycin in humidified conditions of $5 \% \mathrm{CO}_{2}$ at $37^{\circ} \mathrm{C}$.

MTT assay. To test the effect of bakuchiol on human gastric cancer cell viability, NUGC3 cells were seeded in a 96 well plate at a density of $6 \times 10^{4}$ cells $/ \mathrm{ml}$, then treated with 0,20 , $40,60,80,100$ or $120 \mu \mathrm{g} / \mathrm{ml}$ bakuchiol and incubated for $24 \mathrm{~h}$ at $37^{\circ} \mathrm{C}$. The negative control cells were treated with DMSO. Following incubation, $0.5 \mathrm{~g} / \mathrm{ml}$ MTT was added to each well and the plates were further incubated for $3 \mathrm{~h}$ at $37^{\circ} \mathrm{C}$. The medium was then removed and DMSO was added to dissolve the formazan crystals formed. The absorbance was recorded at a $540 \mathrm{~nm}$ wavelength using an iMark (model 550) ELISA microplate absorbance reader (Bio-Rad Laboratories, Inc.).

Cell cycle distribution and cell apoptosis analysis. NUGC3 cells were treated with 0,50 and $100 \mu \mathrm{g} / \mathrm{ml}$ bakuchiol and incubated for $24 \mathrm{~h}$ at $37^{\circ} \mathrm{C}$. The cell lines were collected and cleaned using cold PBS and centrifuged at $1,000 \mathrm{x}$ g for $10 \mathrm{~min}$ at $37^{\circ} \mathrm{C}$. Cold ethanol $70 \%(\mathrm{v} / \mathrm{v})$ was used to fix the pellet at $-20^{\circ} \mathrm{C}$ for $3 \mathrm{~h}$, and the cells were then washed using PBS and $200 \mu \mathrm{l}$ was transferred to a fresh tube. Muse Cell Cycle Assay kit solution $(100 \mu \mathrm{l})$ was added to each well and incubated for $30 \mathrm{~min}$ in the dark at room temperature. The pellet was resuspended in $1 \mathrm{ml}$ RPMI-1640 medium and $100 \mu \mathrm{l}$ was transferred to a fresh tube for the analysis of apoptosis. Again, $100 \mu 1$ of Muse Annexin V and Dead Cell Assay kit solution was added and incubated at room temperature for $30 \mathrm{~min}$ in the dark at $37^{\circ} \mathrm{C}$ and analyzed using the Muse cell analyzer

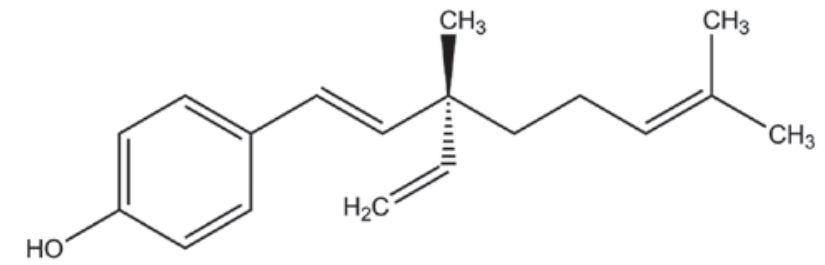

Figure 1. The structure of bakuchiol.

(0500-3115) using Muse count and viable software (version 1.05.0) from EMD Millipore (Billerica, MA, USA).

Morphological changes and DAPI staining. NUGC3 cells were treated with 0,50 and $100 \mu \mathrm{g} / \mathrm{ml}$ bakuchiol and incubated for $24 \mathrm{~h}$ at $37^{\circ} \mathrm{C}$. A total of $1 \times 10^{4}$ cells were then washed with cold PBS at room temperature. Then the cells were fixed with $3.7 \%$ paraformaldehyde $(1 \mathrm{ml})$ and $95 \%$ ethanol at room temperature for $10 \mathrm{~min}$ and followed by washing with PBS. The fixed cells were stained using DAPI (DAPI staining kit solution). The morphological nuclear changes were examined using fluorescence microscopy at $\mathrm{x} 400$ magnification (Model-DMLS) from Leica Microsystems (GmbH, Wetzlar, Germany).

Western blot analysis. NUGC3 cells were treated with 0,50 and $100 \mu \mathrm{g} / \mathrm{ml}$ bakuchiol at $37^{\circ} \mathrm{C}$ for $72 \mathrm{~h}$ and then lysed with NP-40 $(1 \% \mathrm{w} / \mathrm{w})$ ice cold radioimmunoprecipitation assay buffer (Sigma-Aldrich; Merck KGaA, Darmstadt, Germany), sodium deoxycholate $(1 \% \mathrm{w} / \mathrm{v}), \mathrm{SDS}(0.1 \% \mathrm{w} / \mathrm{v}), \mathrm{NaCl}(0.15 \mathrm{M})$, EDTA ( $2 \mathrm{mM}$ ) sodium phosphate buffer (0.01 M, pH 7.2) and sodium fluoride $(50 \mathrm{mM})$. The resultant cell lysates were centrifuged at $3,000 \mathrm{x}$ g for $10 \mathrm{~min}$ at $37^{\circ} \mathrm{C}$ and total cellular protein concentration was determined by Bio-Rad Bradford protein assay method (Bio-Rad Laboratories, Inc.) (9). Equal quantities of protein $(50 \mu \mathrm{g} / \mathrm{lane})$ was separated by SDS PAGE on $12 \%$ gel and then transferred onto a polyvinyldene fluoride membrane. The membrane was blocked with Tris-buffered saline containing Tween-20 and 5\% skimmed milk for $4 \mathrm{~h}$ at $37^{\circ} \mathrm{C}$ and probed with the primary antibodies overnight at $37^{\circ} \mathrm{C}$, followed by incubation with secondary antibodies conjugated to horseradish peroxidase for $2 \mathrm{~h}$ at $37^{\circ} \mathrm{C}$. The blots were examined using an enhanced chemiluminescence detection kit (GE Healthcare Life Sciences, Chalfont, UK) and quantification was performed using Image $\mathbf{J}$ software from the National Institutes of Health (version 2.8; Bethesda, MD, USA). All assays were performed in triplicate.

Statistical analysis. The statistical analyses were performed using SPSS software (version 20.0; SPSS, Inc., Chicago, IL, USA). The results were expressed as the mean \pm standard deviation of three independent experiments. Differences between the experimental groups were determined using one-way analysis of variance followed by Dunnett's multiple comparison post hoc test. $\mathrm{P}<0.05$ was considered to indicate a statistically significant difference.

\section{Results}

Bakuchiol inhibits NUGC3 cell viability. To determine the concentration of bakuchiol that inhibits cell viability, NUGC3 


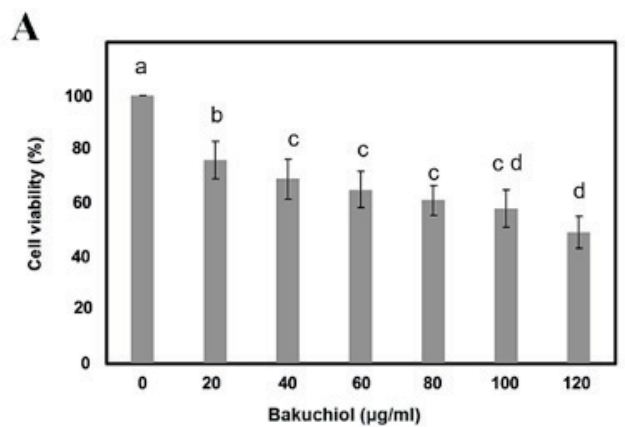

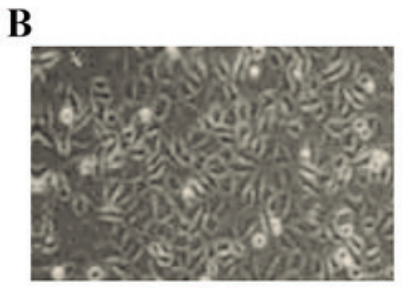

$0 \mu \mathrm{g} / \mathrm{ml}$

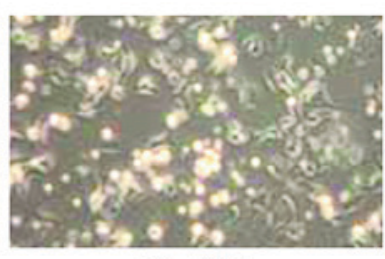

$50 \mu \mathrm{g} / \mathrm{ml}$

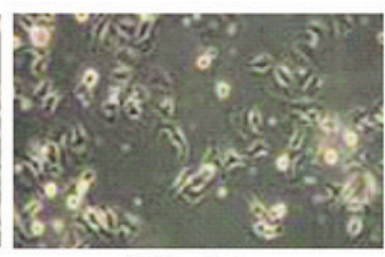

$100 \mu \mathrm{g} / \mathrm{ml}$

Figure 2. Inhibitory effect of bakuchiol on NUGC3 cell viablity. (A) NUGC3 cell viability following treatment with bakuchiol, as determined by MTT assay. (B) Morphological changes in NUGC3 cells following treatment with 0,50 or $100 \mu \mathrm{g} / \mathrm{ml}$ bakuchiol, examined under light microscopy (magnification, $\mathrm{x} 400$ ). Data bearing different letters (a-d) were significantly different from each other (all $\mathrm{P}<0.05)$.

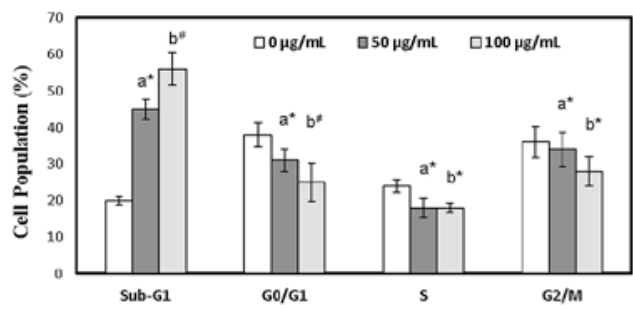

Figure 3. Cell cycle progression of NUGC3 cells treated with 0,50 or $100 \mu \mathrm{g} / \mathrm{ml}$ bakuchiol for $24 \mathrm{~h}$. The data represents the mean \pm standard deviation of three independent experiments. ${ }^{*} \mathrm{P}<0.05$; ${ }^{\#} \mathrm{P}<0.01$. vs. $0 \mu \mathrm{g} / \mathrm{ml}$.

cells were treated with $0,20,40,60,80,100$ or $120 \mu \mathrm{g} / \mathrm{ml}$ bakuchiol for $\sim 24 \mathrm{~h}$, and cell viability was then measured by MTT assay. Following bakuchiol treatment and $24 \mathrm{~h}$ incubation, cell viability was inhibited in a concentration-dependent manner when compared with the control, without bakuchiol treatment $(\mathrm{P}<0.05 ;$ Fig. $2 \mathrm{~A})$. The concentration that produced $50 \%$ inhibition $\left(\mathrm{IC}_{50}\right.$ value) was revealed to be $\sim 120 \mu \mathrm{g} / \mathrm{ml}$. Therefore, bakuchiol concentrations of 0,50 and $100 \mu \mathrm{g} / \mathrm{ml}$ were used for further examination. Microscopic study indicated changes in the cell structure, including visible shrinkage of cells and reduced cell counts, in bakuchiol treated cells compared with controls (Fig. 2B).

Bakuchiol induces apoptosis in NUGC3 cells. Cell cycle distribution and the apoptotic cell population in bakuchiol-treated NUGC3 cells was determined using flow cytometry analysis. Bakuchiol treatment elevated the percentage of sub-G1 cells from $13 \%$ to 28 and $39 \%$ at $50(\mathrm{P}<0.05)$ and $100 \mu \mathrm{g} / \mathrm{ml}$ $(\mathrm{P}<0.01)$, respectively (Fig. 3). Meanwhile, bakuchiol treatment significantly reduced the cell population of $\mathrm{G}_{0} / \mathrm{G} 1, \mathrm{~S}$ and $\mathrm{G} 2 / \mathrm{M}$ compared with the control $(\mathrm{P}<0.05 ;$ Fig. 3$)$. In addition, the effect of bakuchiol on apoptosis induction in NUGC3 cells was examined using Annexin V-fluorescein isothiocyanate/propidium iodide double staining and flow cytometry.

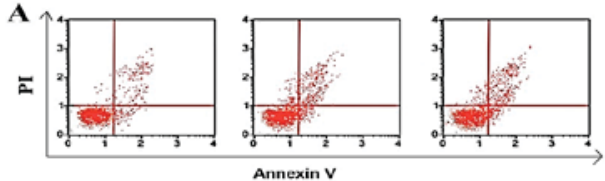

B
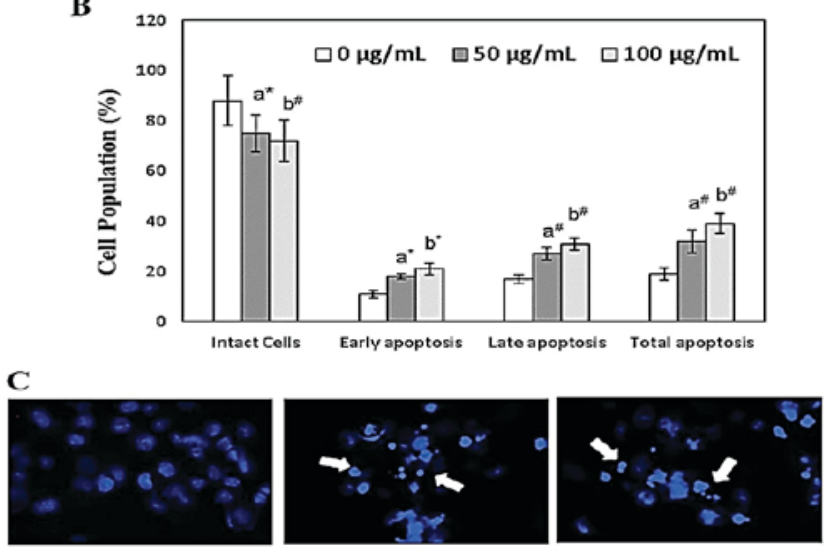

Figure 4. (A) Effect of 0,50 or $100 \mu \mathrm{g} / \mathrm{ml}$ bakuchiol treatment on apoptosis of NUGC 3 cells. (B) The data are expressed as the mean \pm standard deviation of three independent experiments. (C) DAPI staining of NUGC3 cells with nuclear fragmentations indicated by white arrows, analyzed using a fluorescent microscope (magnification, $\mathrm{x} 400$ ). ${ }^{*} \mathrm{P}<0.05 ;{ }^{*} \mathrm{P}<0.01$. vs. $0 \mu \mathrm{g} / \mathrm{ml}$.

The mild elevation of sub-G1 cells in the untreated group was attributed to the effect of DMSO on NUGC3 cells.

Treatment with bakuchiol $(50 \mu \mathrm{g} / \mathrm{ml} ; \mathrm{P}<0.05$ and $100 \mu \mathrm{g} / \mathrm{ml} ; \mathrm{P}<0.01)$ significantly increased the percentage of early apoptosis, late apoptosis and total apoptosis in NUGC3 cells in a concentration dependent manner compared with the control (Fig. 4A and B). Nuclear fragmentation and apoptotic organelles were observed following 50 and $100 \mu \mathrm{g} / \mathrm{ml}$ bakuchiol treatment, using DAPI staining (Fig. 4C). These data suggested that bakuchiol treatment induced cell death in NUGC3 cells. 

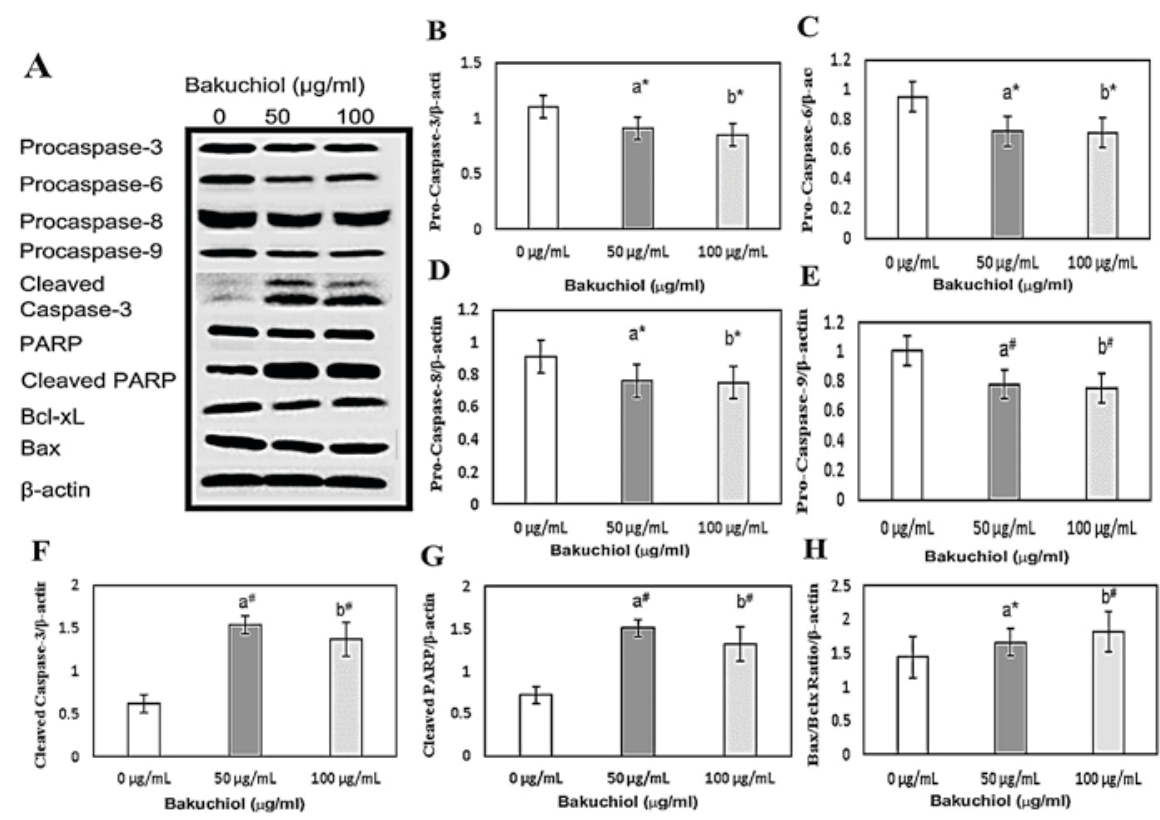

Figure 5. (A) Western blot analysis of caspase activation and PARP cleavage in NUGC3 cells treated with $0,50 \mathrm{or} 100 \mu \mathrm{g} / \mathrm{ml}$ bakuchiol for $24 \mathrm{~h}$. Densitometric analyses of (B) procaspase-3, (C) procaspase-6, (D) procaspase-8, (E) procaspase-9, (F) cleaved caspase-3, (G) PARP and (H) Bax:Bcl-xL. " $\mathrm{P}<0.05$; ${ }^{~} \mathrm{P}<0.01$. vs. $0 \mu \mathrm{g} / \mathrm{ml}$. PARP, poly (ADP-ribose) polymerase; Bax, B cell lymphoma-2 associated X, apoptosis regulator; Bcl-xL, B cell lymphoma-extra large.

Caspase activation and PARP cleavage was induced by bakuchiol. To confirm whether bakuchiol-induced apoptosis was caspase dependent, western blotting analysis was performed (Fig. 5A). Furthermore, the levels of apoptosis-associated proteins, Bax and Bcl-xL, were measured in bakuchiol-treated NUGC3 cells. Levels of procaspase-3,6,8 and 9 were significantly decreased following treatment with 50 and $100 \mu \mathrm{g} / \mathrm{ml}$ bakuchiol treatment compared with the control ( $\mathrm{P}<0.05$; Fig. 5B-E, respectively), while cleaved caspase-3 and cleaved PARP levels were significantly elevated following 50 and $100 \mu \mathrm{g} / \mathrm{ml}$ bakuchiol treatment compared with the control ( $\mathrm{P}<0.01$; Fig. 5F and G, respectively). The ratio of Bax/Bcl-xL in NUGC3 cells was also significantly upregulated following bakuchiol $(50 \mu \mathrm{g} / \mathrm{ml} ; \mathrm{P}<0.05$ and $100 \mu \mathrm{g} / \mathrm{ml} ; \mathrm{P}<0.01)$ treatment compared with the control (Fig. 5H). These data suggested that bakuchiol treatment induced caspase-dependent apoptosis in NUGC3 cells.

Bakuchiol-induced apoptosis is regulated by the phosphoinositide 3-kinase (PI3K)/AKT and mitogen-activated protein kinase (MAPK) pathways in NUGC3 cells. Cell proliferation and apoptosis are regulated by the PI3K/AKT and MAPK signaling pathways. As AKT activity is maintained by phosphorylation, the phosphorylation of PI3K/AKT and MAPK was analyzed using western blotting during bakuchiol-induced apoptosis in NUGC3 cells (Fig. 6A). Bakuchiol treatment $(50$ and $100 \mu \mathrm{g} / \mathrm{ml})$ resulted in significant decrease $(50 \mu \mathrm{g} / \mathrm{ml} ; \mathrm{P}<0.01$ and $100 \mu \mathrm{g} / \mathrm{ml} ; \mathrm{P}<0.05)$ in the levels of phosphorylated AKT (p-Akt) compared with the control (Fig. 6B). Furthermore, phosphorylated ERK1/2, JNK and p38 levels were significantly upregulated upon treatment with bakuchiol compared with the control $(\mathrm{P}<0.01$; Fig. $6 \mathrm{C}-\mathrm{E}$, respectively). These experimental findings suggested that bakuchiol induced apoptosis in NUGC3 cells by regulation of the PI3K/AKT and MAPK signaling pathways.
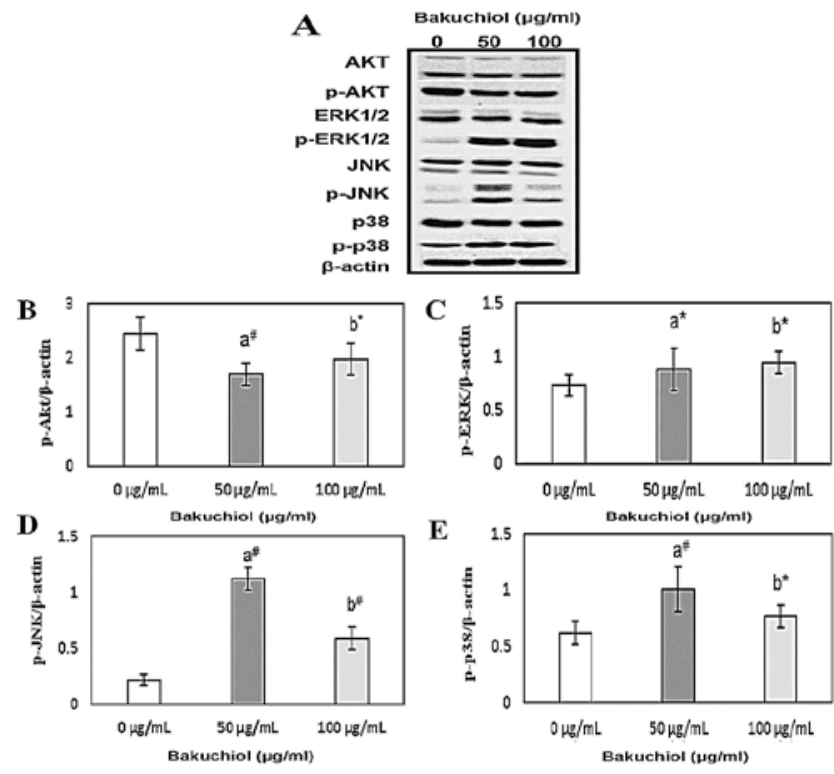

Figure 6. (A) Effect of 0,50 or $100 \mu \mathrm{g} / \mathrm{ml}$ bakuchiol treatment for $24 \mathrm{~h}$ on PI3K/AKT and MAPK signaling pathways in NUGC3 cells, analyzed by western blotting. Densitometric analyses of (B) p-Akt, (C) p-ERK1/2, (D) p-JNK and (E) p-p38. ${ }^{*} \mathrm{P}<0.05 ;{ }^{*} \mathrm{P}<0.01 . v s .0 \mu \mathrm{g} / \mathrm{ml}$. PI3K, phosphoinositide 3-kinase; AKT, protein kinase B; MAPK, mitogen-activated protein kinase; p-, phosphorylated; ERK1/2, extracellular signal related kinase 1/2; JNK, c-Jun $\mathrm{N}$-terminal kinase.

\section{Discussion}

The aim of the present study was to investigate whether bakuchiol treatment induced gastric cancer cell death, and to further determine the underlying molecular mechanisms of bakuchiol-induced apoptosis in NUGC3 cells. Successful medicinal treatment using chemotherapeutic agents is primarily dependent on their potential to induce apoptosis 
in cancer cells (10). Isolated bakuchiol, which is a major chemical component of Psoralea corylifolia, a member of the Leguminosae family (11), is one of the primary medicinal plants in Indian Ayurveda and Chinese traditional medicinal treatments owing to its inhibitory properties on DNA polymerase (12) and topoisomerase II (13). A previous study on bakuchiol observed that its antibacterial activity was significantly enhanced via chemical modification to obtain reduction of MIC up to 8-fold against Gram (+) and (-) bacteria (14). The present study focused on the anticancer effects of bakuchiol against human gastric cancer cell lines.

The results of the MTT assay revealed that bakuchiol significantly reduced NUGC3 cell viability in a concentration dependent manner. Type I programmed cell death, or apoptosis, is the primary mechanism by which different anti-tumor and chemoprotective agents, inclusive of naturally derived products, exert anti-cancer properties (15). Earlier reports demonstrated that abnormalities in the cell cycle may result in apoptosis in various cancer cell lines $(16,17)$. Bakuchiol treatment resulted in sub-G1 phase cell accumulation in NUGC3 cells. Annexin V-FITC/PI double staining confirmed the induction of apoptosis and nuclear fragmentation and apoptotic organelles were observed in bakuchiol-treated NUGC3 cells. These data revealed that bakuchiol suppressed NUGC gastric cancer cell viability and was responsible for the induction of apoptosis.

To explore the involved molecular mechanisms, western blotting was performed and the results indicated that procaspase-3,6,8 and 9 expression levels were significantly decreased. The vital caspase is caspase- 3 , which activates PARP cleavage and results in the induction of the apoptosis process. Elevated cleaved caspase-3 expression concomitantly induced the cleavage of PARP. These data confirmed that bakuchiol induced apoptosis in a caspase-3 dependent manner. Mitochondrial apoptotic functions are regulated by apoptotic regulatory proteins of the Bcl-2 family. Cell viability and death were determined by the levels of Bcl-2 family pro-and anti-apoptotic proteins. The ratio of Bax and $\mathrm{Bcl}-\mathrm{xL}$ has been demonstrated to be an apoptosis determining factor. In the present work, Bax protein expression levels remained the same while Bcl-xL levels were significantly downregulated, but following bakuchiol treatment the upregulation of the Bax:Bcl-xL ratio was observed in NUGC3 cells. When released from the mitochondria to the cytosol, cytochrome $\mathrm{c}$ has previously been observed to interact with apoptotic peptidase activating factor-1 and thereby lead to $\mathrm{Bax} / \mathrm{Bcl}-\mathrm{xL}$ ratio increment, thus activating caspase- 3 and resulting in apoptosis (18).

To further evaluate the molecular mechanisms and involved signaling pathways in bakuchiol-induced apoptosis, PI3K/AKT and MAPK pathway phosphorylation levels were analyzed by western blotting. Bakuchiol inhibited levels of p-AKT, the downstream target of PI3K, which is known to control proliferation and cell apoptosis. Similar to the results of the present study, PI3K/AKT signaling pathway inhibition induces apoptosis in different cancer types $(18,19)$. The MAPK signaling pathway also participates in cell viability, proliferation and apoptosis, and classified into 3 major divisions: JNK, p83 and ERK MAPKs (20). Although ERK1/2 pathway activation is associated with cell growth and proliferation, it has also been reported to induce apoptosis in T cells via the Fas expression ligand (21). ERK1/2 promotes apoptosis through preventing inactivation of the pro-apoptotic Bcl-2 family member, BCL2 associated agonist of cell death (22). JNK is a representative MAPK downstream kinase family member, which has been reported to maintain Fas and Fas ligand receptor expression in apoptosis (23). JNK is also involved in the apoptosis intrinsic pathway, where activated JNK controls the pro-apoptotic proteins $\mathrm{BH} 3$ interacting domain death agonist and Bax, and induces cytochrome $\mathrm{c}$ release into the cytosol from mitochondria (24). JNK activation results in anti-apoptotic Bcl-2 protein downregulation (25). It has previously been noted that activated p38 induces apoptosis in different cell line $(26,27)$. The results of the present study exhibited similar patterns in which p-ERK, p-JNK and p-p38 levels were increased following bakuchiol treatment in er NUGC3 gastric cancer cells (Fig. 6), indicating the involvement of PI3 K/AKT and MAPKs in bakuchiol-induced apoptosis in NUGC3 cells.

In conclusion, bakuchiol was demonstrated to decrease cell viability and induce caspase-dependent apoptosis in NUGC3 gastric cancer cells. PI3K/AKT and MAPK signaling pathways triggered apoptosis following bakuchiol treatment in the NUGC3 gastric cancer cell line. To the best of our knowledge, the present study is the first to demonstrate the anticancer effect of bakuchiol treatment in NUGC3 cells. Therefore, bakuchiol may be an effective novel chemotherapeutic agent for treating human gastric cancer.

\section{Acknowledgements}

The authors would like to thank Xiangyang Central Hospital, Hubei University of Arts and Science for providing funding support to the present study (grant no. XCH2212-15).

\section{References}

1. Guggenheim DE and Shah MA: Gastric cancer epidemiology and risk factors. J Surg Oncol 107: 230-236, 2013.

2. Herszényi L and Tulassay Z: Epidemiology of gastrointestinal and liver tumors. Eur Rev Med Pharmacol Sci 14: 249-258, 2010.

3. Ren J, Huang HJ, Gong Y, Yue S, Tang LM and Cheng SY: MicroRNA-206 suppresses gastric cancer cell growth and metastasis. Cell Biosci 4: 26: 2014.

4. Jaing JB, Thesson DP, Dusak BA, Dexter DL, Kang GJ and Hamel E: Synthesis and biological evaluation of 2-styrylquinazolin-4(3H)-ones, a new class of antimitotic anticancer agents which inhibit tubulin polymerization. J Med Chem 33: 1721-1728, 1990.

5. Zouhiri F, Danet M, Bénard C: Normad-Boyle M, Mouscadet JF, Leh H, Thomas CM, Mbemba G, d'Angelo J and Desmaële D: HIV-1 replication inhibitors of the styrylquinoline class: Introduction of an additional carboxyl group at the $\mathrm{C}-5$ position of the quinolone. Tetrahedron Lett 46: 2201-2205, 2005.

6. Eltahla AA, Lim KL, Eden JS, Kelly AG, Mackenzie JM and White PA: Nonnucleoside inhibitors of norovirus RNA Polymerase: Scaffolds for rational drug design. Antimicrob Agents Chemother 58: 3115-3123, 2014.

7. Lee IK, Han MS, Lee MS, Kim YS and Yun BS: Styrylpyrones from the medicinal fungus Phellinus baumii and their antioxidant properties. Bioorg Med Chem Lett 20: 5459-5461, 2010.

8. Bapat SA, Mali AM, Koppikar CB and Kurrey NK: Stem and progenitor like cells contribute to the aggressive behaviour of human epithelial ovarian cancer. Cancer Res 65: 3025-3029, 2005.

9. Bradford MM: A rapid and sensitive method for the quantitation of microgram quantities of protein utilizing the principle of protein-dye binding. Anal Biochem 72: 248-254, 1976.

10. Vansteenkiste J: Improving patient management in metastatic non-small cell lung cancer. Lung Cancer 57 (Suppl 2): S12-S17, 2007. 
11. Chevalier A and Kindersley D: The encyclopedia of medicinal plants. ISBN 9-780751-303148 London, 1996.

12. Duke JA and Ayensu ES: Medicinal plants of China Inc. ISBN 0-917256, 20: 4, 1985

13. Sun NJ, Woo SH, Cassady JM and Snapka RM: DNA polymerase and topoisomerase II inhibitors from Psoralea corylifolia. J Nat Prod 61: 362-366, 1998 .

14. Katsura H, Tsukiyama RI, Suzuki A and Kobayashi M: In vitro antimicrobial activities of bakuchiol against oral microorganisms. Antimicrob Agents Chemother 45: 3009-3013, 2001.

15. Reddy MV, Thota N, Sangwan PL, Malhotra P, Ali F, Khan IA, Chimni SS and Koul S: Novel bisstyryl derivatives of bakuchiol: Targeting oral cavity pathogens. Eur J Med Chem 45: 3125-3134, 2010.

16. Shi Y: Caspase activation: Revisiting the induced proximity model. Cell 117: 855-858, 2004.

17. Park SJ, Ahmad F, Philp A, Baar K, Williams T, Luo H, Ke H, Rehmann H, Taussig R, Brown AL, et al: Resveratrol ameliorates aging-related metabolic phenotypes by inhibiting cAMP phosphodiesterases. Cell 148: 421-433, 2012.

18. Lee DH, Park KI, Park HS, Kang SR, Nagappan A, Kim JA, Kim EH, Lee WS, Hah YS, Chung HJ, et al: Flavonoids isolated from Korea Citrus aurantium L. Induce G2/M phase arrest and apoptosis in human gastric cancer AGS cells. Evid Based Complement Alternat Med 2012: 515901, 2012.

19. Hussain AR, Al-Rasheed M, Manogaran PS, Al-Hussein KA, Platanias LC, Al Kuraya K and Uddin S: Curcumin induces apoptosis via inhibition of PI3'-kinase/AKT pathway in acute T cell leukemias. Apoptosis 11: 245-254, 2006
20. Gururajan M, Dasu T, Shahidain S, Jennings CD, Robertson DA, Rangnekar VM and Bondada S: Spleen tyrosine kinase (Syk), a novel target of curcumin, is required for B lymphoma growth. J Immunol 178: 111-121, 2007.

21. Raman M, Chen W and Cobb MH: Differential regulation and properties of MAPKs. Oncogene 26: 3100-3112, 2007.

22. van den Brink MR, Kapeller R, Pratt JC, Chang JH and Burakoff SJ: The extracellular signal-regulated kinase pathway is required for activation-induced cell death of T cells. J Biol Chem 274: 11178-11185, 1999.

23. Basu S, Bayoumy S, Zhang Y, Lozano J and Kolesnick R: BAD enables ceramide to signal apoptosis via Ras and Raf-1. J Biol Chem 273: 30419-30426, 1998

24. Faris M, Kokot N, Latinis K, Kasibhatla S, Green DR, Koretzky GA and $\mathrm{Nel} \mathrm{A}$ : The c-Jun N-terminal kinase cascade plays a role in stress-induced apoptosis in Jurkat cells by up-regulating Fas ligand expression. J Immunol 160: 134-144, 1998.

25. Dhanasekaran DN and Reddy EP: JNK signaling in apoptosis. Oncogene 27: 6245-6225, 2008.

26. Kang YJ, Zhou ZX, Wang GW, Buridi A and Klein JB Suppression by metallothionein of doxorubicin-induced cardiomyocyte apoptosis through inhibition of p38 mitogen-activated protein kinases. J Biol Chem 275: 13690-13698, 2000.

27. Sinha K, Das J, Pal PB and Sil PC: Oxidative stress: The mitochondria-dependent and mitochondria-independent pathways of apoptosis. Arch Toxicol 87: 1157-1180, 2013. 